\title{
ELECTROCHEMICAL OXIDATION OF VT6 TITANIUM ALLOY IN OXALIC ACID SOLUTIONS
}

\author{
Alexei Pilipenko1, ${ }^{\circledR}$, Antonina Maizelis' ${ }^{1}$,Hanna Pancheva', Yulia Zhelavska ${ }^{1}$
}

https://doi.org/10.23939/chcht14.02.221

\begin{abstract}
The influence of the electrolysis parameters on the process of VT6 titanium alloy oxidizing in oxalic acid solutions is presented. It is shown that the nature of cell voltage-time curves for the alloy samples depends on the current density used. The interference-colored oxide films are formed on the surface of the alloy at the anodic current density above $0.5 \mathrm{~A} \cdot \mathrm{dm}^{-2}$. The maximal thickness and the oxide film color are determined by the cell voltage and do not depend on other electrolysis parameters. The results of oxidation in oxalic and sulfuric acids solutions made it possible to establish the similarity of cell voltage-time dependencies and the time of oxide film formation with maximal thickness for these electrolysis conditions.
\end{abstract}

Keywords: oxidation, titanium, cell voltage-time dependence, oxide film.

\section{Introduction}

Titanium is one of active metals, though a natural oxide film forms on its surface under normal conditions. This film acts as a protective barrier, which causes the passivity of titanium in various media $[1,2]$. It is possible to obtain synthetic oxide films on titanium, which possess certain properties. Such films are functional coatings that are used to improve corrosion resistance, biocompatibility, and labeling of medical devices made of titanium $[3,4]$. Synthetic films are characterized by a certain thickness and homogeneity of the chemical composition, which ensures their rather high protective properties. Additionally, the formation of highly developed surface occurs during oxidation, which makes it possible to improve its contact with a bone tissue [5]. Natural films are unsuitable for this purpose due to their small thickness $(0.005-0.006 \mu \mathrm{m})$. Oxide films are obtained for titanium by several methods: thermal and plasma oxidation $[6,7]$, combined electrochemical and hydrothermal processing [8], diffusion [9], electrochemical oxidation [10-14]. The

\footnotetext{
${ }^{1}$ National Technical University "Kharkiv Polytechnic Institute"

2, Kyrpychova St., 61002 Kharkiv, Ukraine

o.pilipenko1984@gmail.com

(C) Pilipenko A., Maizelis A., Pancheva H., Zhelavska Yu., 2020
}

last method of oxidation, which is sometimes called anodizing, is the most common.

Pure titanium is not strong enough; therefore products made of titanium cannot be used under conditions of varying mechanical loads. Titanium alloys are used for manufacturing implants. Particularly, VT6 alloy (3.5-5.3\% of $\mathrm{V}, 5.3-6.8 \%$ of $\mathrm{Al})$ is widely used for this purpose. It has the favorable combination of strength and technological properties [12, 13]. The chemical resistance of titanium alloys is generally lower than resistance of pure titanium and it decreases with the increase in the number of alloying elements $[15,16]$. The electrochemical oxidation (anodizing) method is used to improve the corrosion resistance and biocompatibility of titanium implants. The method allows controlling thickness and structure of the film [4]. Anodizing allows reducing the probability of sample surface destruction, crumbling and penetration of metal particles in the surrounding body tissues, which limits the service life of titanium implants $[4,5,16]$. Titanium anodizing is carried out in acid and salt solutions. Frequently, oxalic acid solutions are used for this purpose. The product processsing in such solutions leads to formation of interferencecolored oxide film on titanium $[10,11]$. There are no systematic data on the effect of the oxidation regime (current density and electrolyte concentration) on the maximal possible thickness and color of the oxide film in the literature. The thickness of the film determines the properties of the oxide coating and directly affects the duration of electrochemical treatment of products, which is the main technological parameter of the process. Therefore, establishing the correlation between the electrolysis regime and the time for reaching the maximal thickness of the oxide film is an actual engineering problem.

The purpose of this study was to determine the effect of electrolysis parameters on the process of electrochemical oxidizing of VT6 titanium alloy in oxalic acid.

\section{Experimental}

Samples made of VT6 titanium alloy in the form of plates of a rectangular shape $(70 \times 20 \times 5 \mathrm{~mm})$ were used for the studies. The samples were grinded with a flap wheel to 
remove slight and rough scratches. The ground samples were degreased with an aqueous suspension of sodium carbonate and washed with tap water. Degreased samples were etched in a mixture of nitric and hydrofluoric acids (3:1), washed with tap and distilled water.

Electrolysis was carried out in the galvanostatic mode, setting the value of cell voltage in the range of 10 $100 \mathrm{~V}$ with a step of $10 \mathrm{~V}$ using the B5-49 power supply. Switching of the power supply from the constant current mode to the constant voltage mode by the relay was used as a signal for the end of the oxidizing process. The current control was carried out using M2038 voltammeter, and the voltage change was controlled using Keithley2000 multimeter.

A $250 \mathrm{~cm}^{3}$ beaker made of chemically resistant glass was used as an electrolysis cell. Oxidation was carried out at the temperature of 293-295 K. To prevent the heating of electrolyte by the passing current, the beaker was placed in a glass crystallizing tank $\left(5 \mathrm{dm}^{3}\right)$, filled with water. The counter electrode was made of lead. Oxidation was carried out in solutions of oxalic acid, prepared from pure grade reagent using distilled water. The etching solution was prepared from $\mathrm{HNO}_{3}$ and $\mathrm{HF}$ of pure analytical grade.

\section{Results and Discussion}

The most informative for researching the anodizing process is the study of time dependence of the cell voltage (the $V(t)$ dependence). This dependence connects the change in a cell voltage with the duration of electrolysis (Fig. 1) and allows studying the kinetics of film growth. Experimental data made it possible to find out that the shape of the $V(t)$ dependences is determined by the used current density $j_{a}$ and it is the same for the entire range of formation voltage. Fig. 1 shows the $V(t)$ dependences for VT6 alloy obtained at $40 \mathrm{~V}$ in the solution with $100 \mathrm{~g} \cdot \mathrm{dm}^{-3}$ of $\mathrm{H}_{2} \mathrm{C}_{2} \mathrm{O}_{4}$. In the current densities range of $0.2-0.5 \mathrm{~A} \cdot \mathrm{dm}^{-2}$, the dependences are non-linear and they often are not reproduced (Fig. 1, curves 1 and 2). For $j_{\mathrm{a}}=0.2 \mathrm{~A} \cdot \mathrm{dm}^{-2}$, a given value of $V$ is not achieved at all. This is due to the fact that the process of oxide formation consists of two processes: the electrochemical formation of the film and its dissolution as a result of chemical interaction with the components of the electrolyte. The first process leads to the increase in the film thickness and, accordingly, to the increase in its electrical resistance. According to Ohm's law, this leads to the increase in the cell voltage drop, the major part of which is within the oxide film. Chemical dissolution reduces the film thickness. The appearance of a horizontal plateau (Fig. 1, curve 1) indicates that the oxidation is carried out in a steady state, in which the rate of electrochemical formation of the film becomes equal to the rate of its chemical dissolution. As the $j_{a}$ value increases up to $0.5 \mathrm{~A} \cdot \mathrm{dm}^{-2}$ (Fig. 1, curve 2), a plateau appears on the curve, after which a cell voltage gradually increases and finally achieves the given value of $V$. The process is characterized by an inhibition period, which indicates a change of film formation kinetics and the transition of the film structure to a form, which is less sensitive to the electrolyte action.

The increase in the current density up to $1-5 \mathrm{~A} \cdot \mathrm{dm}^{-2}$ causes the linear shape of the dependences (Fig. 1, curves 3-6), which indicates the formation of low-porous films with good protective properties. The color of the resulting film depends on its thickness, the value of which is determined by the given value of cell voltage.

The accordance of the oxide film color obtained for VT6 alloy in $\mathrm{H}_{2} \mathrm{C}_{2} \mathrm{O}_{4}$ solution and the cell voltage is given in Table 1.

The dependence of time for reaching the preset $V$ on the current density has a characteristic shape that remains for the whole series of curves obtained for samples oxidized in the same regime (Fig. 2, curves 1-3). With a consequent increase in voltage, the increase in time $t$ is observed (Fig. 2, curves 1-3). The value of time for reaching the preset value of $V$ corresponds to time for achieving the maximal film thickness for these electrolysis conditions and represents the maximal possible duration of electrolysis.

The dependence of time for reaching the maximal film thickness on $V$ for a number of identical current densities has a linear shape (Fig. 3). The slope of these dependences does not remain constant; it decreases with the increase in cell voltage.

Experimental data (Fig. 4) show that the change in $\mathrm{H}_{2} \mathrm{C}_{2} \mathrm{O}_{4}$ concentration in the solution within 5-100 $\mathrm{g} \cdot \mathrm{dm}^{-3}$ do not affect the duration of film growth. The maximal film thickness depends only on the preset value of $V$.

Table 1

The accordance of the color of the oxide film and the value of cell voltage

\begin{tabular}{|c|c|}
\hline Cell voltage $V, \mathrm{~V}$ & Film color \\
\hline 10 & brown \\
\hline 20 & blue \\
\hline 30 & light blue \\
\hline 40 & light green \\
\hline 50 & yellow \\
\hline 60 & golden \\
\hline 70 & crimson \\
\hline 80 & dark-turquoise \\
\hline 90 & light turquoise \\
\hline 100 & green \\
\hline
\end{tabular}




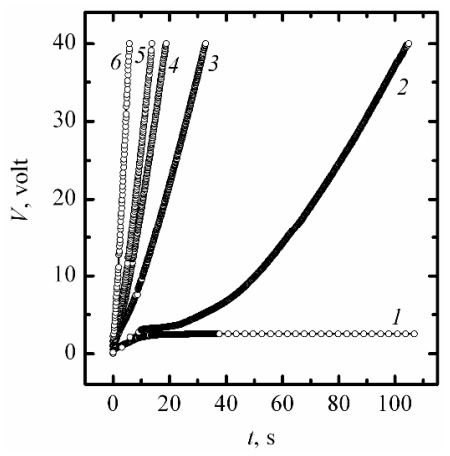

Fig. 1. $V(t)$ dependence obtained for VT6 alloy in $\mathrm{H}_{2} \mathrm{C}_{2} \mathrm{O}_{4}$ at different $j_{\mathrm{a}}, \mathrm{A} \cdot \mathrm{dm}^{-2}: 0.2$ (1); 0.5 (2); 1 (3); 0.75 (4); 2 (5) and 5 (6). $V=40 \mathrm{~V} ; c_{\mathrm{A}}=100 \mathrm{~g} \cdot \mathrm{dm}^{-3}$

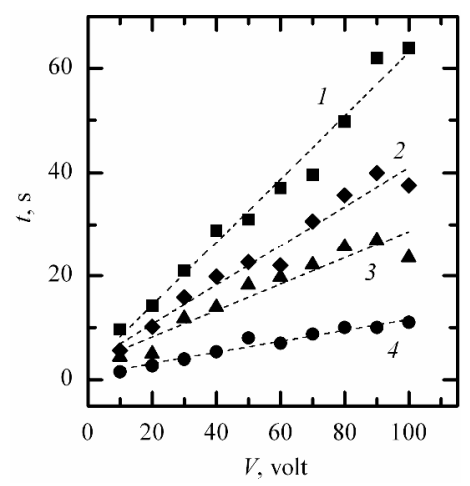

a)

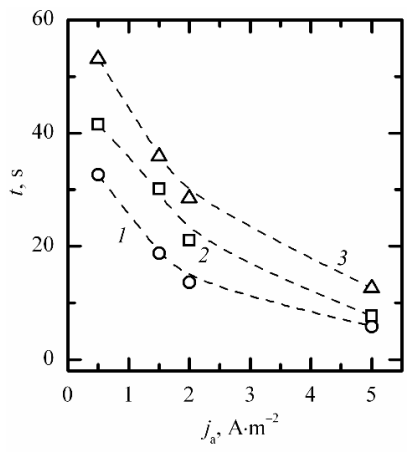

Fig. 2. Dependence of time for reaching the maximal film thickness on the current density during electrochemical oxidation of VT6 alloy in $\mathrm{H}_{2} \mathrm{C}_{2} \mathrm{O}_{4}$ at different cell voltages, V: $40(1) ; 60(2)$ and $80(3) \cdot c_{\mathrm{A}}=100 \mathrm{~g} \cdot \mathrm{dm}^{-3}$

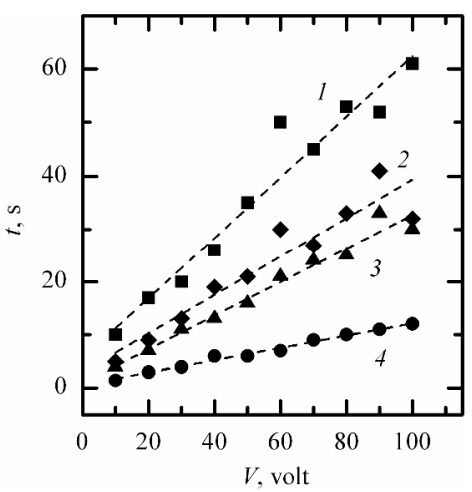

b)

Fig. 3. Dependence of time for reaching the maximal film thickness on the cell voltage during VT6 alloy oxidizing in $\mathrm{H}_{2} \mathrm{C}_{2} \mathrm{O}_{4}$ at $c_{\mathrm{A}}=10 \mathrm{~g} \cdot \mathrm{dm}^{-3}(\mathrm{a})$ and $c_{\mathrm{A}}=100 \mathrm{~g} \cdot \mathrm{dm}^{-3}(\mathrm{~b})$. Current density, $\mathrm{A} \cdot \mathrm{dm}^{-2}: 1(1) ; 1.5(2) ; 2$ (3) and 5 (4)

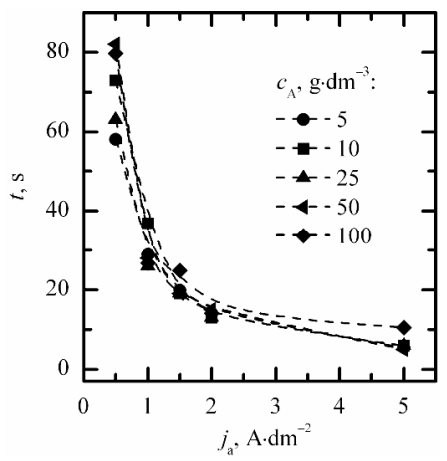

a)

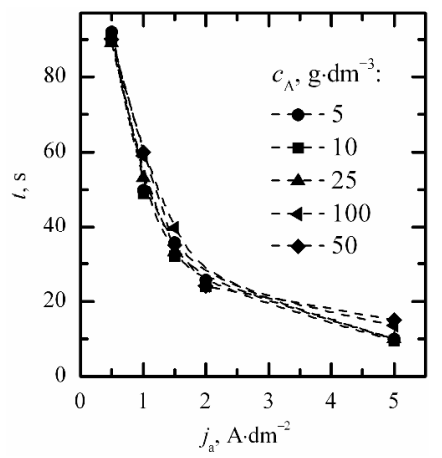

b)

Fig. 4. Dependence of time for reaching the maximal film thickness on the current density during electrochemical oxidizing of VT6 alloy in $\mathrm{H}_{2} \mathrm{C}_{2} \mathrm{O}_{4}$ at the cell voltage of $40 \mathrm{~V}$ (a) and $100 \mathrm{~V}$ (b)

For electrolytes with the same concentration of $\mathrm{H}_{2} \mathrm{C}_{2} \mathrm{O}_{4}$, the dependence of time for reaching the maximal film thickness on $V$ has a rectilinear shape (Fig. 5). The slope of the dependences in all cases is the same for the whole range of acid concentrations studied. Some of the deviations seen in Fig. 5 are due to inaccuracies in time measurement, as well as the difference in the surface area of the oxidized samples.
Thus, the obtained data show that the maximal thickness of the oxide film obtained during oxidizing in $\mathrm{H}_{2} \mathrm{C}_{2} \mathrm{O}_{4}$ depends only on the preset value of cell voltage.

To explain the experimental results obtained during oxidation, it is necessary to discuss the following features of the process: i) what solution components are oxygen donors in the process of oxide film formation; ii) whether the resulting oxide films are dielectric; iii) why only the cell voltage affects the maximal thickness of the oxide film. 


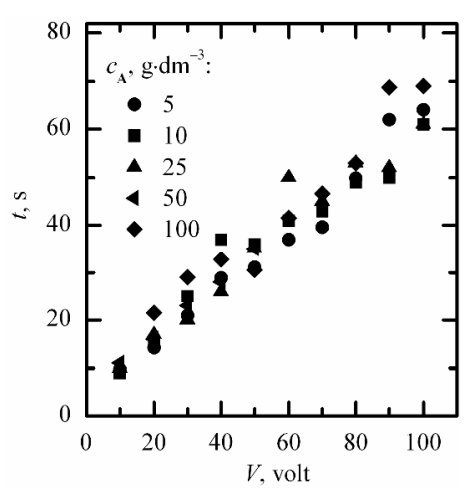

a)

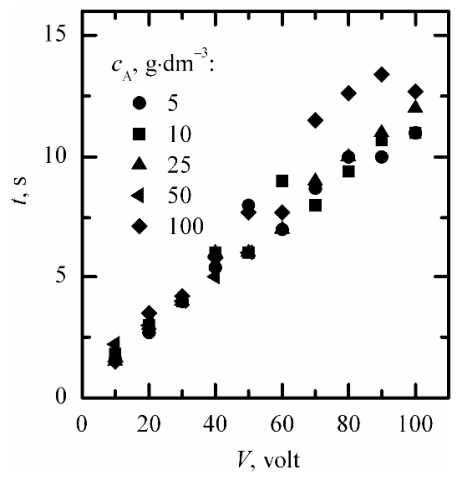

b)

Fig. 5. Dependences of time for reaching the maximal film thickness on the cell voltage during electrochemical oxidation of VT6 alloy in $\mathrm{H}_{2} \mathrm{C}_{2} \mathrm{O}_{4}$ at the current density of $1 \mathrm{~A} \cdot \mathrm{dm}^{-2}$ (a) and $5 \mathrm{~A} \cdot \mathrm{dm}^{-2}$ (b)

Generally, the titanium anodic oxidation can be represented as:

$$
\mathrm{Ti}-4 \mathrm{e}+2 \mathrm{H}_{2} \mathrm{O} \rightarrow \mathrm{TiO}_{2}+4 \mathrm{H}^{+}
$$

Reaction (1) is the result of a complex process, one of the stages being titanium ionization. If the oxide film consists of $\mathrm{TiO}_{2}$, the titanium ionization reaction at the "metal-oxide" interface will be given by:

$$
\mathrm{Ti}-4 \mathrm{e} \rightarrow \mathrm{Ti}^{4+}
$$

The electrons released by the reaction (2) enter the external circuit and form an anodizing current. The $\mathrm{Ti}^{4+}$ ions migrate through the ionic lattice of the oxide to its outer surface under the influence of the electric field gradient.

Oxygen needed for the oxide film formation during anodic polarization comes from the electrolyte. Theoretically, the oxygen donors can be anions of electrolyte $\left(\mathrm{C}_{2} \mathrm{O}_{4}{ }^{2-}\right)$ or water molecules. If $\mathrm{H}_{2} \mathrm{O}$ molecules are the source of oxygen, then oxidation in another electrolyte solution with the same electrolysis parameters will not cause a change in the $V(t)$

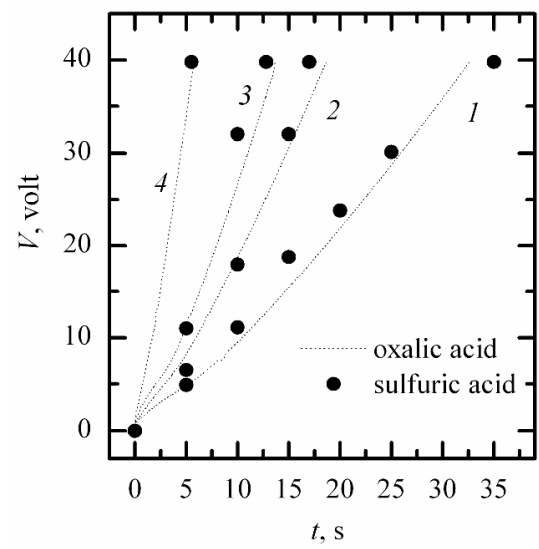

Fig. 6. $V(t)$ dependences obtained for VT6 alloy oxidizing in $\mathrm{H}_{2} \mathrm{C}_{2} \mathrm{O}_{4}$ and $\mathrm{H}_{2} \mathrm{SO}_{4}$ at different $j_{\mathrm{a}}, \mathrm{A} \cdot \mathrm{dm}^{-2}: 0.2$ (1); 0.5 (2); 1 (3); 0.75 (4); 2 (5) and 5 (6). $V=40 \mathrm{~V} ; c_{\mathrm{A}}=100 \mathrm{~g} \cdot \mathrm{dm}^{-3}$ dependences. A solution of sulfuric acid was chosen as such electrolyte. The results of the study are shown in Fig. 6. For comparison, the figure presents data obtained under the same conditions in $\mathrm{H}_{2} \mathrm{C}_{2} \mathrm{O}_{4}$. It can be seen that generally the $V(t)$ dependence for VT6 alloy in $\mathrm{H}_{2} \mathrm{SO}_{4}$ has the same shape as the dependence obtained for $\mathrm{H}_{2} \mathrm{C}_{2} \mathrm{O}_{4}$. Their character is determined by a current density used and it is the same for the entire investigated range of cell voltage.

Fig. 7 shows dependences of time of reaching the maximal thickness of oxide film obtained for $\mathrm{H}_{2} \mathrm{C}_{2} \mathrm{O}_{4}$ and $\mathrm{H}_{2} \mathrm{SO}_{4}$. It can be seen, that satisfactory agreement of the experimental data is observed. This indicates that the nature of electrolyte does not affect the process of electrochemical growth of the film.

The results presented in Figs. 6 and 7 confirm that the mechanism of oxidation in $\mathrm{H}_{2} \mathrm{C}_{2} \mathrm{O}_{4}$ and $\mathrm{H}_{2} \mathrm{SO}_{4}$ is the same. Otherwise, the coincidence of the $V(t)$ dependencies would be unlikely. Therefore, the most likely oxygen donor in both electrolytes is a water molecule.

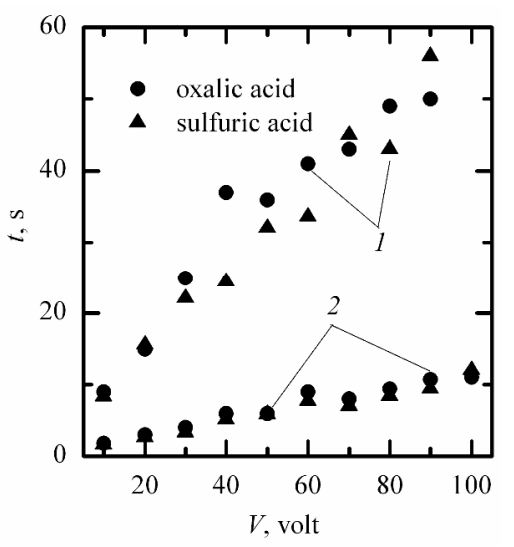

Fig. 7. Dependences of time for reaching the maximal film thickness on the cell voltage during VT6 alloy oxidizing in $\mathrm{H}_{2} \mathrm{C}_{2} \mathrm{O}_{4}$ and $\mathrm{H}_{2} \mathrm{SO}_{4}$ at the current density of $1 \mathrm{~A} \cdot \mathrm{dm}^{-2}$ (1) and $5 \mathrm{~A} \cdot \mathrm{dm}^{-2}(2) \cdot c_{\mathrm{A}}=10 \mathrm{~g} \cdot \mathrm{dm}^{-3}$ 
The oxide film obtained for titanium as a result of electrochemical oxidation consists of rutile modification of $\mathrm{TiO}_{2}$ with a specific electrical resistance of $10^{13} \Omega \cdot \mathrm{cm}$ [17]. To determine whether the resulting oxide films are dielectric, the following assumption was made. It is known that the film resistance is directly proportional to its thickness. According to Ohm's law:

$$
V=j \rho_{\mathrm{e}} \delta
$$

where $j=\frac{I}{S}$ is the current density through the conductor cross-section, $\mathrm{A} \cdot \mathrm{cm}^{-2} ; \rho_{e}$ is the specific electrical resistance of $\mathrm{TiO}_{2}, \Omega \cdot \mathrm{cm} ; \delta$ is film thickness, $\mathrm{cm}$.

Based on Faraday's law, the thickness of the film growing in a galvanostatic mode is directly proportional to the duration of electrolysis $t$ :

$$
\delta=\frac{j_{a} k_{e} t}{\rho_{o x}}
$$

where $k_{e}$ is the electrochemical equivalent of $\mathrm{TiO}_{2}$ $\left(k_{e}=2.07 \cdot 10^{-4} \mathrm{~g} \cdot \mathrm{A}^{-1} \cdot \mathrm{s}^{-1}\right), \rho_{o x}$ is the density of $\mathrm{TiO}_{2}$ $\left(\rho_{o x}=4.235 \mathrm{~g} \cdot \mathrm{cm}^{-3}\right)$.

Substituting (4) into (3) it is possible to obtain the equation for calculating the change in a cell voltage in the process of electrochemical growth of the film:

$$
V=\frac{j_{a}^{2} \rho_{e} k_{e} t}{\rho_{o x}}
$$

Eq. (5) allows to calculate the $V(t)$ dependence for oxide film formation. Fig. 8 shows the $V(t)$ dependence for the solution containing $100 \mathrm{~g} \cdot \mathrm{dm}^{-3} \quad \mathrm{H}_{2} \mathrm{C}_{2} \mathrm{O}_{4}$ at $j_{\mathrm{a}}=2 \mathrm{~A} \cdot \mathrm{dm}^{-2}$; curve 1 presents experimental data, curve 2 is obtained by calculation.

The results presented in Fig. 8 show that the obtained oxide films are not dielectric. The electrical resistance of the oxide obtained by the electrochemical method is much less than the resistance value mentioned in the literature [13, 17-19]. The deviation may be caused by the presence of inclusions in the bulk alloy, as well as electronic defects in the film [20,21]. But the main reason is that the film contains some solution components. This causes reduction in the electrical resistance of oxide. Otherwise, only very thin barrier-type films could be obtained by anodizing, due to a high value of electrical resistance of the resulting oxide would make the further electrochemical oxidation process impossible.

The oxide film formation occurs as a result of a counter-migration of $\mathrm{Ti}^{4+}$ and $\mathrm{O}^{2-}$ ions. The driving force of the process is the presence of considerable electric field strength in the film during anodic oxidation. The increase in film thickness practically ceases when the potential gradient cannot support the ion movement through the oxide $[18,19]$. If the oxide is formed using a constant current density, the voltage across the film should increase linearly. The coefficient of proportionality connecting the oxide film thickness and cell voltage is called the growth constant and varies within the range of $1.9-6.0 \mathrm{~nm} \cdot \mathrm{V}^{-1}$ for titanium [19]. The latter explains the independence of the value of maximal film thickness from the current density and electrolyte concentration. Indeed, the film thickness is determined only by cell voltage. As the film thickness increases, the gradient of the potential drop in the oxide gradually decreases.

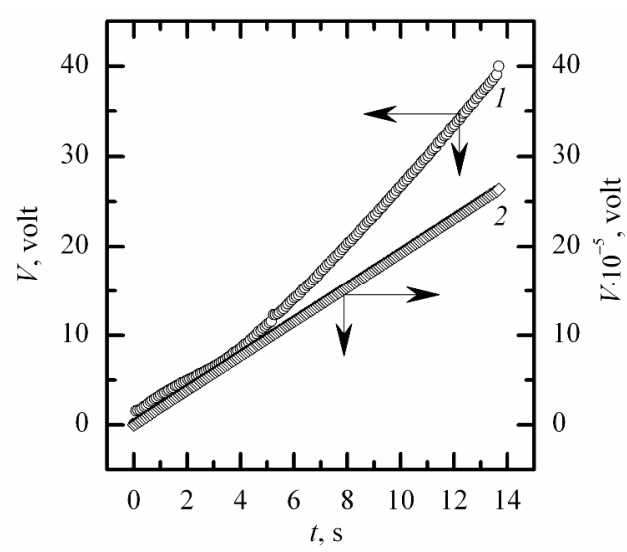

Fig. 8. Calculated (1) and experimental (2) $V(t)$ dependence for VT6 titanium alloy in $\mathrm{H}_{2} \mathrm{C}_{2} \mathrm{O}_{4}$. $j_{\mathrm{a}}=2 \mathrm{~A} \cdot \mathrm{dm}^{-2} ; c_{\mathrm{A}}=100 \mathrm{~g} \cdot \mathrm{dm}^{-3}$

The oxide formation ceases when the critical value of the potential gradient is reached. Therefore, the thickness and color of the film depend only on the value of cell voltage. The increase in $V$ value leads to the increase in electrolysis duration and promotes the formation of thicker oxide film.

\section{Conclusions}

The process of electrochemical oxidation of VT6 titanium alloy in oxalic acid solutions was studied. It is shown that the anode current density has a decisive influence on the character of $V(t)$ dependence for the alloy sample. The continuous oxide film is not formed at $j_{\mathrm{a}}<0.5 \mathrm{~A} \cdot \mathrm{dm}^{-2}$ and the preset cell voltage is not reached. With an increase of $j_{\mathrm{a}}$ above $0.5 \mathrm{~A} \cdot \mathrm{dm}^{-2}$, the linear nature of the dependences is observed, which indicates the formation of low-porous films. Films obtained at current densities $j_{\mathrm{a}}>0.5 \mathrm{~A} \cdot \mathrm{dm}^{-2}$ are interference-colored.

The maximal oxide film thickness is determined by the cell voltage and does not depend on other parameters of the electrochemical treatment of the alloy. For identical values of $V$, the dependence of time for reaching the maximal film thickness on the current density has a linear shape. The change in $\mathrm{H}_{2} \mathrm{C}_{2} \mathrm{O}_{4}$ concentration in solutions in the range of $5-100 \mathrm{~g} \cdot \mathrm{dm}^{-3}$ does not affect the change in time of film growth. 
Water molecule is a donor of oxygen for the formation of an oxide film, which is confirmed by the coincidence of $V(t)$ dependences obtained for $\mathrm{H}_{2} \mathrm{C}_{2} \mathrm{O}_{4}$ and $\mathrm{H}_{2} \mathrm{SO}_{4}$. The kinetics of oxide formation is identical in both cases, which indicates the same mechanism of its formation. The rate of oxide film growth was calculated basing on the assumption that $\mathrm{TiO}_{2}$ dielectric film forms during the electrochemical oxidation. A comparison of the calculated and experimental data showed that the calculated value of $V$ is several orders of magnitude greater than the voltage drop which is actually reached. The obtained results indicate that the electrical resistance of the films does not reach the value of the electrical resistance of the bulk $\mathrm{TiO}_{2}$, i.e. the films are not dielectric.

\section{References}

[1] Ellerbrock D., Macdonald D.: J. Solid State Elecrtochem., 2014, 18, 1485. https://doi.org/10.1007/s10008-013-2334-6

[2] Popa M., Vasilescu E., Drob P. et al.: Mater. Corros., 2002, 53, 51. https://doi.org/10.1002/1521-4176(200201)53:1<51::AIDMACO51>3.0.CO;2-6

[3] Garg H., Bedi G., Garg A.: J. Clin. Diagn. Res., 2012, 6, 319.

[4] Liu X., Chu P., Ding C.: Mat. Sci. Eng. R, 2004, 47, 49. https://doi.org/10.1016/j.mser.2004.11.001

[5] Mandracci P., Mussano F., Rivolo P. et al.: Coatings, 2016, 6, 1. https://doi.org/10.3390/coatings6010007

[6] John A., Jaganathan S., Supriyanto E. et al.: Curr. Sci., 2016, 111, 1003. https://doi.org/10.18520/cs/v111/i6/1003-1015

[7] Diefenbeck M., Mückley T., Schrader C. et al.: Biomaterials, 2011, 32, 8041. https://doi.org/10.1016/j.biomaterials.2011.07.046 [8] Park E., Song Y., Hwang M. et al.: J. Nanosci. Nanotechnol., 2015, 15, 6133. https://doi.org/10.1166/jnn.2015.10469

[9] Lubas M., Sitarz M., Jasinski J. et al.: Spectrochim. Acta A, 2014, 133, 883. https://doi.org/10.1016/j.saa.2014.06.067

[10] Sul Y., Johansson C., Jeong Y. et al.: Med. Eng. Phys., 2001, 23, 329. https://doi.org/10.1016/S1350-4533(01)00050-9

[11] Sul Y., Byon E., Wennerberg A.: Int. J. Oral Maxillofac. Implants, 2008, 23, 631.

[12] Fojt J.: Appl. Surf. Sci., 2012, 262, 63.

https://doi.org/10.1016/j.apsusc.2012.04.012
[13] Veiga C., Davim J., Loureiro A.: Rev. Adv. Mater. Sci., 2012, 32, 133.

[14] Pilipenko A., Pancheva H., Deineka V. et al.: EEJET, 2018, 3, 33. https://doi.org/10.15587/1729-4061.2018.132521

[15] Adya N., Alam M., Ravindranath T. et al.: J. Indian Prosthodont. Soc., 2005, 5, 126. https://doi.org/10.4103/09724052.17104

[16] Mohammed M., Khan Z., Siddiquee A.: Proc. Mat. Sci., 2014, 6, 1610 .

[17] Diebold U.: Surf. Sci. Rep., 2003, 38, 53. https://doi.org/10.1016/S0167-5729(02)00100-0

[18] Blondeau G., Froelicher M., Froment M. et al.: J. Less-

Common. Met., 1977, 56, 215. https://doi.org/10.1016/00225088(77)90043-1

[19] Aladjem A.: J. Mater. Sci., 1973, 8, 688.

https://doi.org/10.1007/BF00561225

[20] Pancheva H., Reznichenko G., Miroshnichenko N. et al.: East.Eur. J. Enterpr. Technol., 2017, 4, 59.

[21] Pilipenko, A., Pancheva, H., Reznichenko et al:: East.-Eur. J. Enterpr. Technol., 2017, 1, 21.

Received: July 25, 2018 / Revised: September 17, 2018 / Accepted: November 15, 2018

\section{ЕЛЕКТРОХІМІЧНЕ ОКСИДУВАННЯ ТИТАНОВОГО СПЛАВУ ВТ6 У РОЗЧИНАХ ОКСАЛАТНОЇ КИСЛОТИ}

Анотація. Приведені результати дослідження впливу параметрів електролізу на прочес оксидування титанового сплаву ВТ6 у розчинах оксалатної кислоти. Показано, що характер формувальних залежностей зразків сплаву залежить від величини використаної густини струму. За анодної густини струму вище 0,5 $A \cdot \partial{ }^{-2}$ на поверхні сплаву утворюються інтерференційно-забарвлені оксидні плівки. Гранична товщина та колір оксидної плівки визначаються напругою формування $i$ не залежать від інших параметрів електролізу. Результати оксидування в розчинах оксалатної та сульфатної кислот дали можливість встановити збіг формувальних залежностей сплаву $i$ часу утворення оксиду максимальної товщиини для даних умов електролізу.

Ключові слова: оксидування, титан, формувальні залежності, оксидна плівка. 